\title{
Pertumbuhan dan Produksi Habbatussauda (Nigella sativa L.) di Tiga Ketinggian di Indonesia
}

\author{
Growth and Production of Black Cumin (Nigela sativa L.) \\ at Three Altitudes in Indonesia
}

\author{
Herlina $^{1,2}$, Sandra Arifin Aziz ${ }^{3}$, Ani Kurniawati ${ }^{3 *}$, dan Didah Nur Faridah ${ }^{4}$ \\ ${ }^{1}$ Program Studi Agronomi dan Hortikultura, Sekolah Pascasarjana, Institut Pertanian Bogor \\ ${ }^{2}$ Fakultas Pertanian, Universitas Dehasen Bengkulu, Jl. Meranti Raya No. 32 Bengkulu, Indonesia \\ ${ }^{3}$ Departemen Agronomi dan Hortikultura, Fakultas Pertanian, Institut Pertanian Bogor \\ (Bogor Agricultural University), Jl. Meranti, Kampus IPB Darmaga, Bogor 16680, Indonesia \\ ${ }^{4}$ Departemen Ilmu \&Teknologi Pangan, Fakultas Teknologi Pertanian, Institut Pertanian Bogor \\ (Bogor Agricultural University), PO. Box 220 Kampus IPB Darmaga, Bogor 16680, Indonesia
}

Diterima 27 September 2016/Disetujui 3 Mei 2017

\begin{abstract}
Black cumin is an annual medicinal aromatic plant, cultivated mainly in mediteranean regions with low temperature (under $20^{\circ} \mathrm{C}$ ). The suitable planting area in the tropic for black cumin need to be studied. The aim of this study was to study the growth and production of black cumin in three altitudes of Indonesia tropical region. The experiment was conducted from June to October 2015 at Bogor Agricultural University experimental station in Leuwikopo, Dramaga (06 56 'S, 106 $73^{\circ}$ 'E, 220 masl); Sukamantri, Ciapus (06 $61^{\prime}$ 'S, 106 $78^{\circ}$ E, 560 masl); and Sari Alam Medicinal Plant Garden in Ciwidey, Bandung $\left(07^{\circ} 09^{\prime} \mathrm{S}, 107^{\circ} 50^{\prime} \mathrm{E}, 1,280\right.$ masl as control). This experiment used a nested design with two factors, i.e. altitudes (220, 560, 1,280 masl) and accesions (India, Kuwait). The variable studied were plant height, leaf area, leaf area index, leaf thickness, capsules per plant, seed per capsule, weight of 1,000 seeds, seeds per plant, and weight of seed per plant. Data was analyzed with compare means difference between low, middle altitude and high altitude as a control (1,280 masl) with t-student test. The result showed black cumin India and Kuwait accessions can be cultivated at low and middle altitude Indonesia tropical region. Plant height of India and Kuwait accession decrease 37.1 and $46.6 \%$ at 560 masl; 21.1 and $24.4 \%$ at 220 masl respectively, and yield decrease 26.9 and $59.4 \%$ at 560 masl and 44.5 and $63.9 \%$ at 220 masl, respectively.
\end{abstract}

Keywords: black cumin, elevation variation, growth and production character

\section{ABSTRAK}

Habbatussauda merupakan tanaman obat aromatik semusim yang umumnya tumbuh di daerah mediteranean dibawah suhu $20^{\circ} \mathrm{C}$. Area penanaman habbatussauda yang sesuai di daerah tropis perlu dipelajari. Penelitian ini bertujuan untuk mempelajari pertumbuhan dan produksi Habbatussauda di tiga ketinggian wilayah tropika Indonesia. Percobaan dilaksanakan dari bulan Juni sampai Oktober 2015 di Kebun Percobaan IPB Leuwikopo, Dramaga (220 mdpl); Sukamantri, Ciapus (560 mdpl); dan Kebun Tanaman Obat Sari Alam, Ciwidey, Bandung (1,280 mdpl sebagai kontrol). Rancangan yang digunakan adalah petak tersarang dua faktor, ketinggian (220, 560, dan 1,280 mdpl) dan aksesi (India, Kuwait). Peubah yang diamati adalah tinggi tanaman, luas daun, indeks luas daun, nisbah luas daun, tebal daun; jumlah kapsul per tanaman, jumlah biji per kapsul, bobot 1,000 biji, jumlah biji per tanaman, dan bobot biji per tanaman. Data dianalisis dengan membandingkan persentase perbedaan setiap peubah di dataran rendah dan menengah dengan dataran tinggi menggunakan uji t-students. Hasil penelitian memperlihatkan jintan hitam dapat tumbuh dan berproduksi di dataran rendah dan menengah tropika Indonesia menggunakan aksesi India dan Kuwait. Penurunan tinggi tanaman sebesar $37.1 \%$ pada aksesi India dan 46.6\% pada aksesi Kuwait di ketinggian 560 mdpl; sebesar 21.1\% pada aksesi India dan $24.4 \%$ pada aksesi Kuwait di ketinggian 220 mdpl. Penurunan produksi sebesar 26.9\% pada aksesi India dan 59.4\% pada aksesi Kuwait di ketinggian 560 mdpl; sebesar 44.5 pada aksesi India dan $63.9 \%$ pada aksesi Kuwait di ketinggian 220 mdpl dibandingkan dengan dataran tinggi (1,280 mdpl) sebagai kontrol.

Kata kunci: habbatussauda, karakter pertumbuhan dan produksi, ketinggian tempat

\footnotetext{
* Penulis untuk korespondensi. e-mail: ani_kurniawati@yahoo.co.id
} 


\section{PENDAHULUAN}

Habbatussauda atau jintan hitam (Nigella sativa L.) adalah tanaman aromatik semusim, merupakan tanaman obat potensial dan telah digunakan di banyak negara termasuk India, negara-negara Arab, dan Eropa tidak hanya sebagai bumbu dan perasa, tetapi juga sebagai bahan obat (Hamid, 2012). Bijinya merupakan sumber natrium, kalsium, kalium, dan zat-zat lain yang berperan dalam kesehatan (Abas-Ali et al., 2012). Tanaman ini dibudidayakan di wilayah mediteranean dan berkembang di berbagai wilayah termasuk India dan Pakistan (Abdolrahimi et al., 2012). Di Pakistan (33 $43^{\prime}$ LU dan $73^{\circ} 06^{\prime}$ BT), tanaman ini memiliki tinggi tanaman $74.6-90.5 \mathrm{~cm}$, produksi biji per tanaman 8.75-9.22 g dan bobot 1000 biji 2.23-2.80 g (Rabbani et al., 2011). Kapsul tanaman berukuran relatif besar, memiliki 3-7 folikel yang masing-masing berisi biji. Ukuran panjang biji normal berkisar 1-5 mm, berwarna hitam atau abu-abu tua dengan permukaan yang agak kasar, bagian dalam biji berwarna putih dan berminyak (Benkaci-Ali et al., 2007).

Di beberapa daerah subtropika, habbatussauda tumbuh di dataran tinggi dengan lingkungan tanah basa dan suhu rendah (di bawah $20^{\circ} \mathrm{C}$ ), dan curah hujan rendah. Di Jordania, tanaman ini tumbuh pada ketinggian 530-880 mdpl dengan kisaran suhu 6.9-17.4 ${ }^{\circ} \mathrm{C}$ dan curah hujan 319.2-462.5 mm per tahun (Talafih et al., 2007); di Turki tumbuh pada jenis tanah liat dengan kadar bahan organik, nitrogen dan phosfat rendah, $\mathrm{pH}$ tinggi (7.8), curah hujan rendah (349.4-424.1 mm per tahun) dan pada kisaran suhu rendah yakni $9.5-10{ }^{\circ} \mathrm{C}$ (Tuncturk et al., 2012); dan di Iran pada ketinggian 1,209 mdpl dengan suhu rata-rata $14{ }^{\circ} \mathrm{C}$ dengan curah hujan $140 \mathrm{~mm}$ per tahun (Khoulenjani dan Salamati, 2011).

Pengembangan budidaya habbatussauda ke daerah tropika seperti Indonesia, akan menghadapi beberapa faktor pembatas pertumbuhan. Faktor pembatas utama adalah iklim, khususnya pada komponen suhu udara. Komponen ini tidak dapat dikendalikan, namun dapat dimodifikasi untuk mendekati kondisi lingkungan asal tanaman. Modifikasi faktor iklim dapat dilakukan dengan mengganti posisi lintang dengan ketinggian wilayah penanaman. Menurut Ahren (2009), penyebaran suhu udara di permukaan bumi dipengaruhi oleh beberapa faktor antara lain jumlah radiasi yang diterima oleh permukaan bumi, pengaruh daratan dan lautan, letak ketinggian dan kemiringan tempat. Suhu udara adalah salah satu faktor iklim yang berpengaruh terhadap laju pertumbuhan dan proses metabolisme tanaman.

Pengaruh suhu terutama terlihat pada laju perkembangan tanaman, seperti perkecambahan, pembentukan daun dan inisiasi organ reproduktif yang berhubungan dengan perubahan permeabilitas membran, diferensiasi, perpanjangan dan pembesaran sel (Potters et al., 2008). Suhu udara pada lokasi penanaman sangat mempengaruhi pertumbuhan dan perkembangan tanaman serta karakteristik pertumbuhan dan hasil tanaman. Peningkatan suhu di atas suhu maksimum kardinal untuk pertumbuhan, membuat tanaman kehilangan warna hijaunya, terjadi perubahan aktivitas fotosintesis dan respirasi yang berpengaruh terhadap siklus hidup dan produktivitas (Ahmad et al., 2010; Barnabas, 2008).

Perbedaan suhu udara (maksimum, minimum dan harian) pada lingkungan tumbuh tanaman akan menghasilkan berbagai respon dalam pertumbuhan dan produksi tanaman. Dalam menghadapi kondisi stress lingkungan, tanaman memberikan respon secara fisiologis dan biokimia, sebagai upaya untuk menerima, menghindari, dan menetralisir pengaruh cekaman. Menurut Sakata dan Higashitani (2008), sifat peka dan toleran suatu tanaman, terutama terhadap cekaman suhu tinggi bergantung pada karakter tiap spesies dan genotip tanaman.

Tanaman memiliki reaksi yang sangat kompleks dalam menghadapi cekaman. Bentuk morfologi, anatomi dan metabolisme tanaman yang berbeda pada aksesi yang berbeda menyebabkan tanaman memiliki respon yang beragam. Ketika cekaman semakin meningkat maka tanaman melakukan penyesuaian diri melalui proses fisiologi dan biokimia melalui perubahan struktur protein kompleks pada kloroplas dan menurunkan aktivitas enzim (Ahmad et al., 2010; Farooq et al., 2009), yang kemudian diikuti perubahan arsitektur tanaman dan morfologi (Hua, 2009; Tian et al., 2009), masa pertumbuhan yang singkat (Barnabas et al., 2008) dan infertilitas polen (Zinn et al., 2010). Periode pembungaan dan reproduksi merupakan periode yang paling sensitif terhadap cekaman suhu tinggi dan hal ini berakibat langsung pada penurunan produktivitas tanaman (Hedhly et al., 2009; Thakur et al., 2010).

Penelitian tentang pertumbuhan dan produksi habbatussauda telah banyak dilakukan di negara asal tanaman ini terutama di dataran tinggi, namun belum banyak diteliti tentang pertumbuhan dan produksi tanaman ini di daerah tropika, khususnya Indonesia. Penelitian tentang habbatussauda di Indonesia dilakukan oleh Ridwan et al. (2014) dan Suryadi (2014), yang melaporkan bahwa tanaman ini dapat tumbuh di wilayah dataran tinggi Indonesia (1,315 mdpl) dengan kisaran suhu minimummaksimum $15.48-26.26{ }^{\circ} \mathrm{C}$. Penelitian ini bertujuan untuk mempelajari pertumbuhan dan produksi habbatussauda di tiga lokasi ketinggian wilayah Indonesia.

\section{BAHAN DAN METODE}

Percobaan dilaksanakan bulan Juni sampai dengan Oktober 2015 di tiga wilayah ketinggian, yaitu dataran rendah di Kebun Percobaan IPB Leuwikopo, Dramaga (220 mdpl), dataran menengah di Kebun Percobaan IPB Sukamantri, Ciapus (560 mdpl), dan dataran tinggi di Kebun Tanaman Obat Sari Alam, Ciwidey, Bandung (1,280 mdpl sebagai kontrol). Analisis karakter morfologi dan fisiologi tanaman dilakukan di Laboratorium Molecular Marker and Spectrophotometry UV-VIS, dan Microtechnique, Departemen Agronomi dan Hortikultura, IPB. Rancangan percobaan yang digunakan adalah rancangan petak tersarang dua faktor, yaitu ketinggian (220, 560 dan 1,280 mdpl), dan aksesi (India dan Kuwait). Setiap kombinasi perlakuan 
diulang 4 kali, sehingga total terdapat 24 satuan percobaan. Masing-masing satuan percobaan terdiri dari 36 tanaman dengan 5 tanaman contoh pada setiap kombinasi perlakuan.

\section{Prosedur Percobaan}

Benih habbatussauda ditanam dalam polybag berdiameter $15 \mathrm{~cm}$ dengan tinggi $30 \mathrm{~cm}$ yang telah diisi media tanam berupa campuran tanah dan pupuk kandang sapi $(1: 1)(\mathrm{v} / \mathrm{v})$ dan kapur pertanian $\left(\mathrm{CaCO}_{3}\right)$ dengan dosis 2 ton $\mathrm{ha}^{-1}$ (3.5 g per polibag). Sebelum ditanam, benih direndam dengan aquades selama 12 jam kemudian ditiriskan dan dikeringanginkan. Benih kemudian ditanam pada polibag yang telah disiapkan dengan jumlah 3 benih per polibag.

Benih dalam polibag kemudian ditumbuhkan di lapang sesuai perlakuan ketinggian tempat di bawah naungan plastik UV berukuran $2.5 \mathrm{~m}$ x $2.5 \mathrm{~m}$ dengan ketinggian naungan $1.25 \mathrm{~m}$ (sebelah timur) dan $1 \mathrm{~m}$ (sebelah barat). Sumber pupuk yang digunakan mengacu pada penelitian Suryadi (2014) yakni pupuk N adalah urea (45\%) dan pupuk $\mathrm{P}$ adalah SP-36 (36\%) dengan dosis $120 \mathrm{~kg} \mathrm{~N} \mathrm{ha}^{-1}$ dan 157 $\mathrm{kg} \mathrm{P}_{2} \mathrm{O}_{5}$ ha $^{-1}$. Pupuk urea diberikan dua kali, yaitu $1 / 2$ dosis pada 1 minggu setelah tanam dan $1 / 2$ dosis pada 5 minggu setelah tanam dan pupuk SP-36 diberikan pada umur 1 minggu setelah tanam Pemeliharaan tanaman dilakukan dengan penyiraman, penyiangan gulma dan pengendalian hama dan penyakit tanaman. Pencatatan data suhu harian, suhu maksimum, suhu minimum dan kelembaban udara dilakukan dua kali sehari (pagi dan sore hari) dan dilakukan setiap hari selama penelitian berlangsung menggunakan thermohygrometer. Data suhu dan kelembaban harian merupakan rata-rata dari dua kali pengamatan.

Pengamatan karakter pertumbuhan terdiri dari peubah tinggi tanaman, luas daun (menggunakan program Block Spot Versi 10 Beta), indeks luas daun (perbandingan luas daun dengan satuan luas bidang yang ditutupi), nisbah luas daun (perbandingan luas daun dengan bobot kering tanaman), dan ketebalan daun. Pengamatan karakter produksi terdiri dari jumlah kapsul per tanaman, jumlah biji per kapsul, bobot 1,000 biji, jumlah biji per tanaman, dan bobot biji per tanaman. Data yang diperoleh dianalisis dengan membandingkan antara data dataran tinggi sebagai kontrol dengan data dataran rendah dan menengah menggunakan uji t-student.

\section{HASIL DAN PEMBAHASAN}

\section{Kondisi Umum Lokasi Penelitian}

Kegiatan penelitian dilakukan di tiga lokasi ketinggian yang masing-masing memiliki karakter iklim mikro berbeda, diantaranya yang disebabkan oleh perbedaan dinamika suhu dan kelembaban (Gambar 1). Rata-rata suhu harian, suhu maksimum, suhu minimum dan kelembaban di dataran tinggi adalah $26.70{ }^{\circ} \mathrm{C}, 33.30{ }^{\circ} \mathrm{C}, 18.00{ }^{\circ} \mathrm{C}$ dan $53 \%$; di dataran menengah adalah $30.20{ }^{\circ} \mathrm{C}, 38.70{ }^{\circ} \mathrm{C}, 19.50{ }^{\circ} \mathrm{C}$ dan $61 \%$; dan di dataran rendah adalah $30.30{ }^{\circ} \mathrm{C}, 39.40{ }^{\circ} \mathrm{C}$, $19.75^{\circ} \mathrm{C}$ dan $69 \%$. Informasi rata-rata suhu dan kelembaban serta karakter media tanam masing-masing lokasi ketinggian dapat dilihat pada Tabel 1.
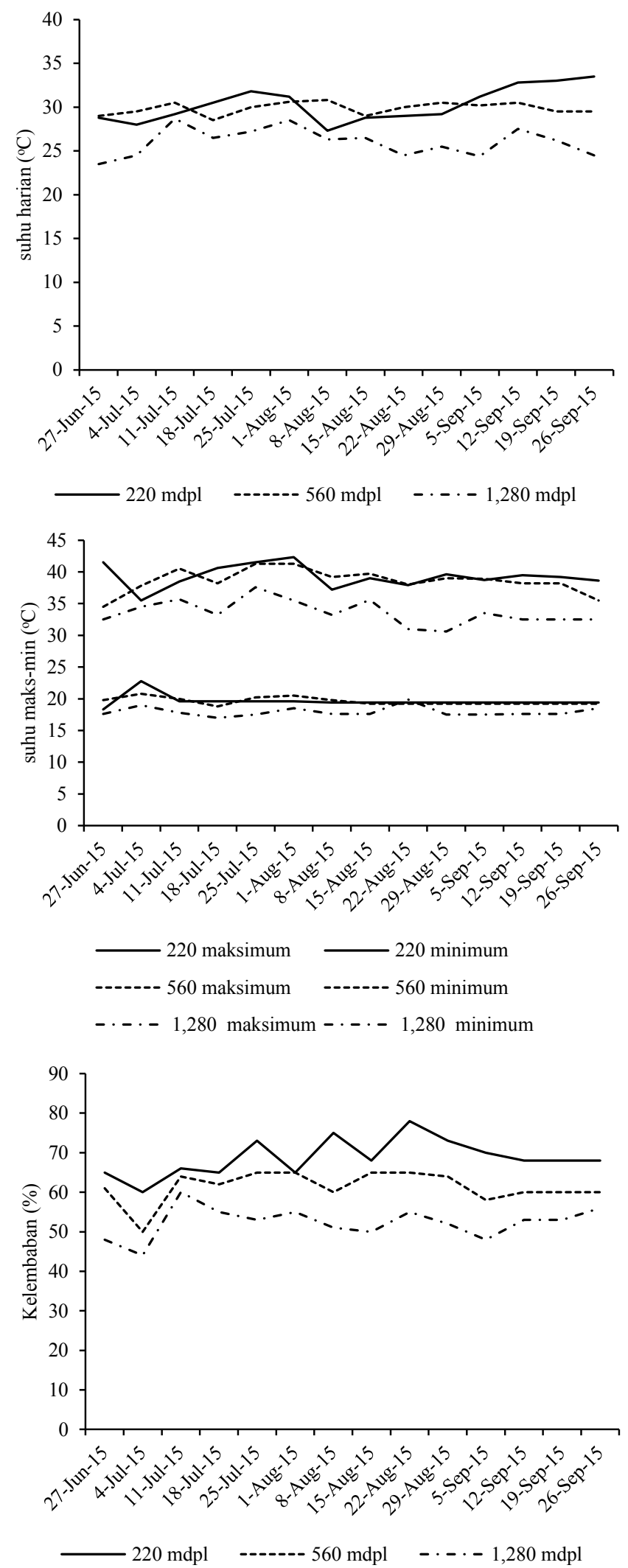

Gambar 1. Dinamika suhu harian, maksimum-minimum, dan kelembaban udara periode Juni-September 2015 
Herlina et al. / J. Agron. Indonesia 45(3):323-330

Tabel 1. Kondisi umum lokasi penelitian dan karakter media tanam

\begin{tabular}{|c|c|c|c|}
\hline Kualifikasi & Dataran tinggi & Dataran menengah & Dataran rendah \\
\hline \multirow[t]{2}{*}{ Lokasi } & KTO Sari Alam Ciwidey & KP IPB Sukamantri & KP IPB Leuwikopo \\
\hline & $7.085 \mathrm{LS}$ & $6.609 \mathrm{LS}$ & $6.563 \mathrm{LS}$ \\
\hline Geografis $^{1)}$ & 107.499 BT & 106.784 BT & 106.726 BT \\
\hline Ketinggian tempat ${ }^{1)}$ & $1,280 \mathrm{mdpl}$ & $560 \mathrm{mdpl}$ & $220 \mathrm{mdpl}$ \\
\hline T harian (Jun-Sep 2015)2) & $26.70^{\circ} \mathrm{C}$ & $30.20^{\circ} \mathrm{C}$ & $30.30^{\circ} \mathrm{C}$ \\
\hline T maksimum (Jun-Sep 2015) & $33.30{ }^{\circ} \mathrm{C}$ & $38.70{ }^{\circ} \mathrm{C}$ & $39.34{ }^{\circ} \mathrm{C}$ \\
\hline T minimum (Jun-Sep 2015) & $18.00{ }^{\circ} \mathrm{C}$ & $19.50{ }^{\circ} \mathrm{C}$ & $19.75^{\circ} \mathrm{C}$ \\
\hline RH (Jun-Sep 2015) $)^{2)}$ & $53(\%)$ & $61(\%)$ & $69(\%)$ \\
\hline \multicolumn{4}{|l|}{ Karakter media tanam ${ }^{3)}$} \\
\hline $\mathrm{pH} \mathrm{H} \mathrm{H}_{2} \mathrm{O}$ & 8 & 7.5 & 6.6 \\
\hline $\mathrm{pH} \mathrm{KCl}$ & 7.6 & 7.2 & 6.4 \\
\hline $\mathrm{C}$ org $(\%)$ & $6.03 \%$ & $6.81 \%$ & $6.09 \%$ \\
\hline N Total (\%) & $2.58 \%$ & $1.26 \%$ & $2.64 \%$ \\
\hline $\mathrm{C} / \mathrm{N}$ & 2.3 & 5.4 & 2.3 \\
\hline $\mathrm{P}_{2} \mathrm{O}_{5}$ tersedia $(\mathrm{ppm})$ & $59.0 \mathrm{ppm}$ & $16.7 \mathrm{ppm}$ & $48.3 \mathrm{ppm}$ \\
\hline $\mathrm{K}$ tersedia $(\mathrm{ppm})$ & $43.8 \mathrm{ppm}$ & $38.9 \mathrm{ppm}$ & $42.5 \mathrm{ppm}$ \\
\hline \multicolumn{4}{|l|}{ KTK (me $100 \mathrm{~g}^{-1}$ ) } \\
\hline $\mathrm{Ca}$ & 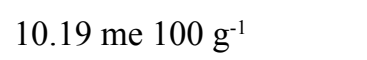 & $23.0 \mathrm{me} 100 \mathrm{~g}^{-1}$ & $5.60 \mathrm{me}^{100 \mathrm{~g}^{-1}}$ \\
\hline $\mathrm{Mg}$ & 10.3 me $100 \mathrm{~g}^{-1}$ & $17.7 \mathrm{me}^{100 \mathrm{~g}^{-1}}$ & 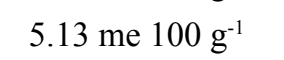 \\
\hline $\mathrm{K}$ & $15.7 \mathrm{me} 100 \mathrm{~g}^{-1}$ & 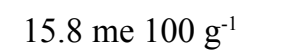 & $13.0 \mathrm{me} 100 \mathrm{~g}^{-1}$ \\
\hline
\end{tabular}

Keterangan: ${ }^{1)}$ Menggunakan program GPS, ${ }^{2)}$ Menggunakan thermohygrometer, ${ }^{3)}$ Dianalisis di Laboratorium PPTK Gambung-Bandung

Pertumbuhan dan Produksi Habbatussauda di Ketinggian 1,280 mdpl sebagai Kontrol

Kondisi iklim mikro pada ketinggian 1,280 mdpl yang digunakan sebagai lokasi penelitian ini relatif lebih mendekati lokasi asal habbatussauda dibandingkan dengan dua ketinggian lainnya, khususnya dari aspek suhu dan kelembaban sehingga kualitas pertumbuhan dan produksi tanaman di lokasi ini secara nyata lebih baik dibandingkan dengan dataran menengah dan rendah. Nilai rerata pertumbuhan dan produksi habbatussauda di ketinggian 1,280 mdpl ditampilkan pada Tabel 2.

Tabel 2. Rerata nilai peubah pertumbuhan dan komponen produksi habbatusaudah di dataran tinggi

\begin{tabular}{|c|c|c|}
\hline \multirow{2}{*}{ Komponen pengamatan } & \multicolumn{2}{|c|}{ Aksesi } \\
\hline & India & Kuwait \\
\hline \multicolumn{3}{|l|}{ Peubah pertumbuhan } \\
\hline Tinggi tanaman (cm) & $52.39 \pm 2.17$ & $60.06 \pm 2.72$ \\
\hline Luas daun $\left(\mathrm{cm}^{2}\right)$ & $221.96 \pm 38.54$ & $283.79 \pm 66.61$ \\
\hline Nisbah luas daun $\left(\mathrm{cm}^{2} \mathrm{~g}^{-1}\right)$ & $67.30 \pm 9.93$ & $99.69 \pm 21.55$ \\
\hline Indeks luas daun & $1.26 \pm 0.21$ & $1.61 \pm 0.37$ \\
\hline Tebal daun (mm) & $0.21 \pm 0.04$ & $0.19 \pm 0.03$ \\
\hline \multicolumn{3}{|l|}{ Peubah komponen produksi } \\
\hline Jumlah kapsul per tanaman (kapsul) & $11.13 \pm 1.84$ & $20.69 \pm$ \\
\hline Jumlah biji per kapsul (biji) & $45.94 \pm 2.48$ & $69.88 \pm 12.36$ \\
\hline Jumlah biji per tanaman (biji) & $511.05 \pm 51.21$ & $1,445.54 \pm 149.69$ \\
\hline Bobot 1,000 biji $(\mathrm{g})$ & $2.37 \pm 0.49$ & $2.80 \pm \quad 0.25$ \\
\hline Bobot biji per tanaman $(\mathrm{g})$ & $1.21 \pm 0.21$ & $4.04 \pm$ \\
\hline
\end{tabular}

Keterangan: nilai merupakan rata-rata $\pm \mathrm{SDev}$ 
Beberapa hasil penelitian di daerah asal tanaman terhadap peubah pertumbuhan dan komponen produksi ditampilkan sebagai informasi pembanding terhadap hasil penelitian yang dilakukan. Penelitian Tuncturk et al. (2011) di Turki (curah hujan 424.1-349.4 mm per tahun, suhu harian rata-rata $10.0-9.5{ }^{\circ} \mathrm{C}$ ), menghasilkan tinggi tanaman 30.9-35.3 cm, dan penelitian El-Mekawy (2012) di Mesir menghasilkan tinggi tanaman antara 54.3-91.5 cm. Luas daun diinformasikan oleh Shah et al. (2006) dan Shah (2011) di India (suhu maksimum $23.2{ }^{\circ} \mathrm{C}$ dan suhu minimum 17.4 ${ }^{\circ} \mathrm{C}$, kelembaban 52-64\%) sebesar 291.70-430.16 $\mathrm{cm}^{2}$ per tanaman. Sementara itu, untuk peubah jumlah kapsul per tanaman di Turki (curah hujan 424.1-349.4 mm per tahun, suhu harian rata-rata $10.0-9.5^{\circ} \mathrm{C}$ ) dilaporkan sebesar 5.5-7.5 kapsul (Tuncturk et al., 2012), di India (27 $7^{\circ}$ ' $\mathrm{LU}$ dan $78^{\circ}$ 51' BT, ketinggian 187.5 mdpl) sebanyak 15.1-33.1 kapsul (Shah, 2007), dan di Mesir 9.67-29.25 kapsul (El-Mekawy, 2012). Jumlah biji per kapsul dilaporkan di India (27 53' LU dan $78^{\circ}$ 54' BT, ketinggian $187.45 \mathrm{mdpl}$ ) sebanyak 52.01-55.21 biji (Shah et al., 2006), di Turki 52.4-55.1 biji (Tuncturk et al., 2012) dan 52.2-56.2 biji (Tuncturk et al., 2011). Bobot biji per tanaman dilaporkan di Pakistan berkisar pada nilai 8-83-9.22 g (Rabbani et al., 2011), di India 0.70-1.45 g (Shah, 2011) dan 1.2-2.6 g (Shah, 2007).

Secara umum terlihat bahwa hasil penelitian di dataran tinggi Indonesia berada dalam rentang rata-rata nilai di daerah asal tanaman, sehingga hasil penelitian di ketinggian 1,280 mdpl ini relatif dapat digunakan sebagai patokan (kontrol) atas pertumbuhan dan produksi tanaman habbatussauda di wilayah dataran rendah dan menengah.

\section{Karakter Pertumbuhan Tanaman Habbatussauda di Dataran Rendah dan Menengah}

Wilayah dataran rendah dan menengah yang digunakan sebagai lokasi penelitian yaitu pada ketinggian 220 dan 560 mdpl. Ketinggian $220 \mathrm{mdpl}$ memiliki rata-rata suhu harian $30.30{ }^{\circ} \mathrm{C}$ dan ketinggian $560 \mathrm{mdpl}$ memiliki rata-rata suhu harian $30.20{ }^{\circ} \mathrm{C}$ sehingga kedua ketinggian tersebut memiliki rata-rata suhu harian $3.60{ }^{\circ} \mathrm{C}$ dan $3.50{ }^{\circ} \mathrm{C}$ lebih tinggi dibandingkan dengan dataran tinggi (1,280 mdpl). Suhu lingkungan tumbuh yang lebih tinggi, menghasilkan karakter tanaman dengan kualitas pertumbuhan vegetatif dan produksi lebih rendah. Menurut Wahid et al. (2007) perbedaan rata-rata suhu harian merupakan angka yang paling tepat digunakan sebagai penentu respon tanaman terhadap suhu tinggi. Persentase perbedaan nilai rerata karakter pertumbuhan di dataran menengah dan rendah terhadap kontrol (dataran tinggi) ditampilkan pada Gambar 2.

Tinggi tanaman adalah salah satu peubah yang paling mudah untuk dijadikan indikator secara visual terhadap kualitas pertumbuhan tanaman. Tinggi tanaman aksesi India yang tumbuh di ketinggian 560 dan 220 mdpl secara nyata lebih rendah 37.1 dan $21.1 \%$ dibandingkan dengan kontrol, begitu pula tinggi tanaman aksesi Kuwait di ketinggian 560 dan $220 \mathrm{mdpl}$ secara nyata lebih rendah 46.6 dan $24.4 \%$ dibanding kontrol (Gambar 2). Namun jika dibandingkan dengan penelitian Ridwan et al. (2014) dimana tinggi tanaman habbatussauda yang dihasilkan adalah 23.0 $\mathrm{cm}$ pada ketinggian 1,350 mdpl, maka tinggi tanaman habbatussauda yang tumbuh di ketinggian $220 \mathrm{mdpl}$, lebih tinggi 79.8\% untuk aksesi India dan 97.3\% untuk aksesi Kuwait. Sementara itu, tinggi tanaman habbatussauda yang tumbuh diketinggian $560 \mathrm{mdpl}$, lebih tinggi 43.3\% untuk aksesi India dan 45.4\% untuk aksesi Kuwait.

Luas daun habbatussauda yang tumbuh di ketinggian 560 dan 220 mdpl pada penelitian ini sebesar 193.31 dan $163.56 \mathrm{~cm}^{2}$ per tanaman untuk aksesi India dan 209.57 dan $294.15 \mathrm{~cm}^{2}$ per tanaman untuk aksesi Kuwait (Tabel 3). Dibandingkan kontrol, luas daun tidak berbeda nyata antar ketinggian untuk kedua aksesi, kecuali untuk aksesi Kuwait di ketinggian 560 mdpl yang nyata lebih rendah 26.2\% (Gambar 2). Penelitian Ridwan et al. (2014)

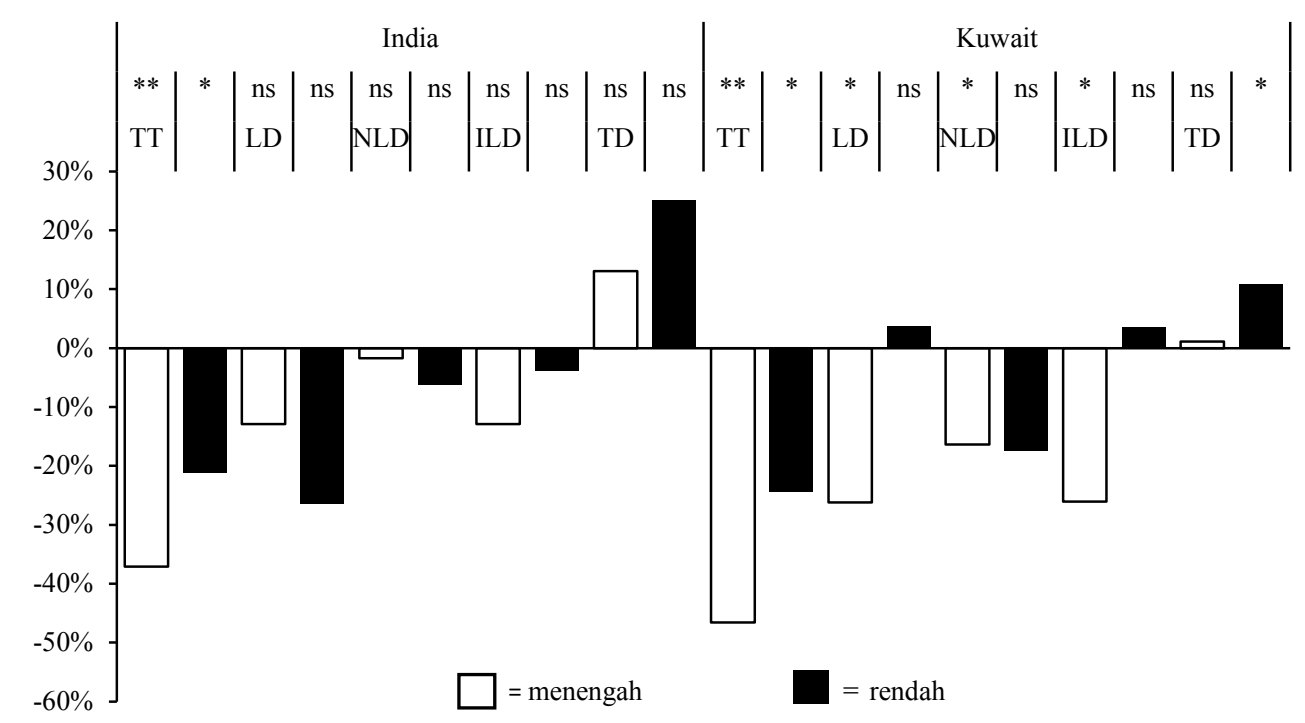

Gambar 2. Persentase perbedaan peubah pertumbuhan dibanding kontrol (dataran tinggi). tn $=$ tidak nyata; $*$ dan** $=$ berbeda nyata pada a 5 dan $1 \%$ menurut uji t-student. Keterangan: TT = tinggi tanaman, $\mathrm{LD}=$ luas daun, NLD = nisbah luas daun, ILD = indeks luas daun, $\mathrm{TD}=$ tebal daun 
menghasilkan luas daun tertinggi pada 10 MST sebesar 18.5 $\mathrm{cm}^{2}$ per tanaman, sehingga dapat diinformasikan bahwa pada penelitian ini luas daun habbatussauda aksesi India di ketinggian $220 \mathrm{mdpl}$ lebih besar 8 kali dan di $560 \mathrm{mdpl}$ lebih besar 10 kali; sementara itu, untuk aksesi Kuwait di ketinggian 220 mdpl lebih besar 11 kali dan di ketinggian 560 mdpl lebih besar 16 kali dibanding hasil penelitian Ridwan et al. (2014).

Pengukuran nisbah luas daun dan indeks luas daun terkait dengan nilai luas daun yang dihasilkan tanaman. Nilai nisbah luas daun yang rendah mencerminkan rendahnya jumlah daun yang terbentuk yang dapat disebabkan oleh rendahnya nilai pertumbuhan atau gugurnya daun. Hal ini akan mempengaruhi aktivitas fotosintesis dan pada akhirnya berpengaruh pada pembentukan bahan kering tanaman. Ridwan et al. (2014) menyatakan bahwa nilai nisbah luas daun habbatussauda menurun dengan meningkatnya umur tanaman.

Indeks luas daun sangat tergantung pada kualitas aktivitas metabolisme tanaman. Nisbah luas daun dan indeks luas daun pada penelitian ini tidak berbeda pada tiap ketinggian untuk kedua aksesi, kecuali untuk aksesi Kuwait di ketinggian 560 mdpl dengan nilai nisbah luas daun dan indeks luas daun 16.4 dan $26.1 \%$ lebih rendah dibanding kontrol (Gambar 2). Nisbah luas daun mencerminkan kemampuan daun dalam satuan luasan tertentu untuk memproduksi biomassa atau bahan kering, sedangkan indeks luas daun digunakan sebagai indikator dalam pertumbuhan tanaman, yaitu sebagai salah satu peubah untuk mengetahui intensitas radiasi yang diintersepsi oleh daun sehingga dapat diduga nilai biomassanya.

Aksesi Kuwait pada ketinggian 220 mdpl menghasilkan daun yang nyata lebih tebal 10.9\% dibanding kontrol. Namun tidak berbeda nyata di ketinggian 560 mdpl. Aksesi India menghasilkan ketebalan daun yang tidak berbeda nyata antara dataran rendah dan menengah dibanding kontrol (Gambar 2). Meningkatnya ketebalan daun aksesi Kuwait di dataran rendah (220 mdpl) berhubungan dengan upaya tanaman mempertahankan diri dari pengaruh suhu tinggi dengan meningkatkan jumlah sel palisade, sehingga daun menjadi lebih tebal dengan ukuran lebih kecil dengan tujuan mengurangi penguapan (Muhuria et al., 2006).

Nilai peubah pertumbuhan tanaman yang bervariasi diatas memperlihatkan peran suhu terhadap kualitas pertumbuhan tanaman. Dinamika suhu udara pada lokasi penanaman (Gambar 1) sangat mempengaruhi pertumbuhan dan perkembangan tanaman. Penelitian Lumingkewas et al. (2015) memperlihatkan bahwa suhu berpengaruh nyata pada tinggi tanaman, luas daun dan jumlah biji tanaman soba. Secara umum hasil penelitian ini memperlihatkan bahwa perbedaan suhu karena perbedaan ketinggian berpengaruh terhadap peubah pertumbuhan tinggi tanaman, luas daun, nisbah luas daun, indeks luas daun dan tebal daun.

\section{Karakter Produksi Tanaman Habbatussaudah di Dataran Rendah dan Menengah}

Karakter produksi tanaman di lingkungan tumbuh yang baru (daerah tropika) dan relatif sangat berbeda adalah merupakan bagian terpenting untuk diketahui. Pada penelitian ini hasil pengamatan terhadap karakter produksi tanaman dan besar persentase perbedaannya dibandingkan kontrol ditampilkan pada Gambar 3.

Hasil penelitian memperlihatkan bahwa terdapat perbedaan nyata pada beberapa komponen produksi antara kontrol dan dan kedua ketinggian lainnya. Aksesi Kuwait di ketinggian $560 \mathrm{mdpl}$ secara nyata mengalami penurunan jumlah kapsul per tanaman sebesar $33.2 \%$, penurunan jumlah biji per kapsul sebesar $38.3 \%$, penurunan jumlah biji per tanaman sebesar $58.1 \%$; sedangkan aksesi India nyata mengalami penurunan jumlah biji per kapsul di 220 mdpl sebesar $35.1 \%$. Peubah lain seperti bobot 1,000 butir

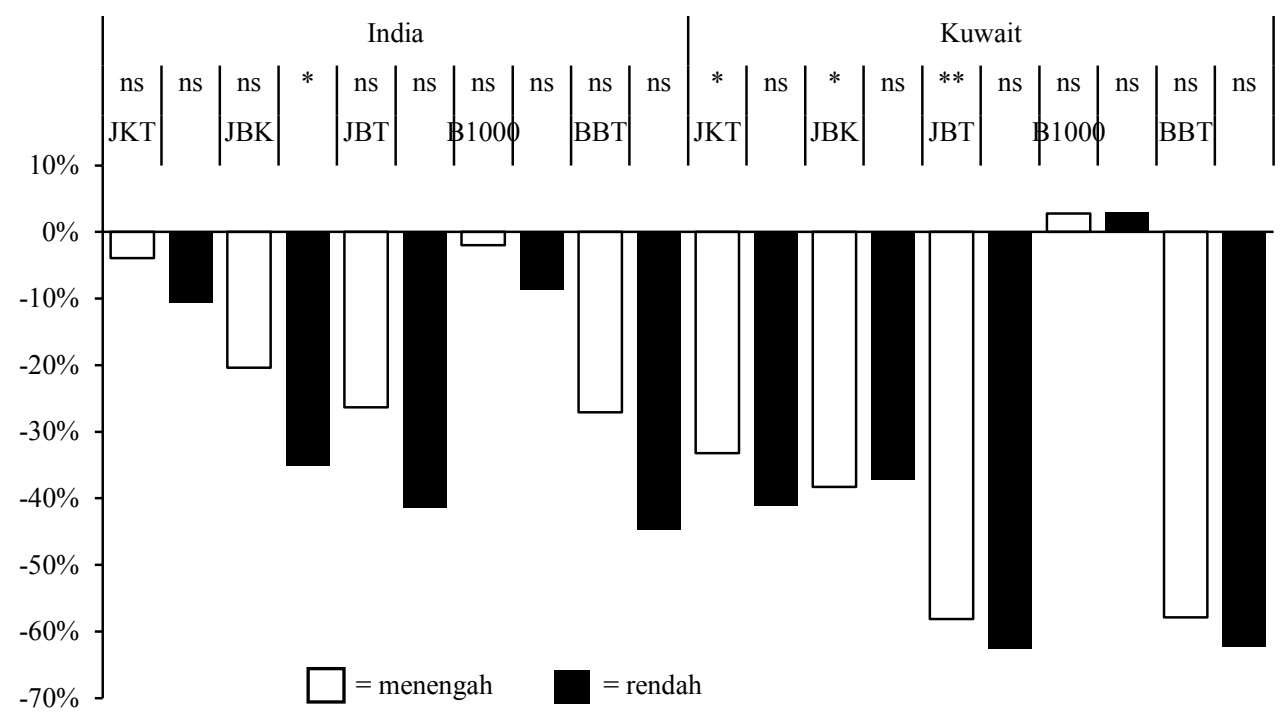

Gambar 3. Persentase perbedaan rata-rata komponen produksi dibanding kontrol (dataran tinggi). tn $=$ idak nyata, $* \& * *$ berbeda nyata pada $\alpha 5$ dan $1 \%$ menurut uji t-student. Keterangan: JKT $=$ jumlah kapsul per tanaman, JBK $=$ jumlah biji per kapsul, JBT $=$ jumlah biji per tanaman, B1,000 = bobot seribu biji, BBT = bobot biji per tanaman 
dan bobot biji per tanaman pada kedua aksesi di 560 dan $220 \mathrm{mdpl}$, meskipun tidak berbeda nyata secara statistik namun tetap mengalami penurunan nilai dibanding kontrol (Gambar 3). Hasil penelitian sebelumnya oleh Ridwan et al. (2014) menghasilkan jumlah biji per kapsul paling tinggi sebesar 30.3 biji. Jika dibandingkan dengan penelitian tersebut, maka jumlah biji per kapsul yang dihasilkan pada penelitian ini untuk aksesi Kuwait di ketinggian $220 \mathrm{mdpl}$ lebih tinggi $42.3 \%$ dan di ketinggian 560 mdpl lebih tinggi $44.8 \%$, sedangkan untuk aksesi India di 560 mdpl lebih tinggi $20.5 \%$. Hal ini memperlihatkan bahwa kedua aksesi habbatussauda yang digunakan pada penelitian ini mampu tumbuh dan berproduksi di wilayah dataran rendah dan menengah Indonesia.

Bobot 1,000 butir biji aksesi Kuwait pada ketinggian 220 mdpl yaitu 2.874 g dan aksesi India 2.167 g (Gambar 3). Jika dibandingkan dengan bobot awal benih yang digunakan adalah sebesar $2.3742 \mathrm{~g}$ untuk aksesi Kuwait dan $2.2514 \mathrm{~g}$ untuk aksesi India, ukuran biji yang dihasilkan di ketinggian 220 mdpl untuk aksesi Kuwait mengalami peningkatan ukuran sebesar $21.1 \%$, sedangkan aksesi India mengalami penurunan ukuran sebesar $3.7 \%$.

Penurunan respon pertumbuhan dan produksi pada dataran rendah dan menengah diduga berhubungan dengan penghambatan beberapa proses pertumbuhan yang diakibatkan oleh cekaman suhu yang lebih tinggi pada dataran rendah dan menengah. Gratani et al. (2006) menyatakan pada suhu yang lebih tinggi perkembangan daun didominasi oleh peningkatan jumlah sel daripada ukuran sel, dan menyebabkan daun lebih tebal, sehingga menurunkan efisiensi penangkapan cahaya yang akhirnya dapat menurunkan laju fotosintesis. Penurunan laju fotosintesis disebabkan oleh meningkatnya aktivitas enzim klorofillase dan menurunnya sejumlah pigment fotosintesis (Sharkey dan Zhang, 2010) yang pada akhirnya akan menyebabkan tanaman mengalami penurunan produksi (Zinn et al., 2010). Selisih suhu harian di ketinggian $220 \mathrm{mdpl}$ dan kontrol sebesar $3.60{ }^{\circ} \mathrm{C}$ pada penelitian ini menurunkan produksi biji per tanaman sebesar 44.5 dan $63.9 \%$ masing-masing pada habbatussauda aksesi India dan Kuwait. Ortiz et al. (2008) menginformasikan bahwa peningkatan suhu 3-4 ${ }^{\circ} \mathrm{C}$ dapat menurunkan produksi $15-35 \%$ di Afrika dan Asia, dan 25-35\% di Timur Tengah.

\section{KESIMPULAN}

Habbatussauda aksesi India dan Kuwait dapat tumbuh dan berproduksi di tiga ketinggian wilayah Indonesia. Suhu harian dan kelembaban udara yang lebih tinggi pada ketinggian $560 \mathrm{mdpl}\left(30.20^{\circ} \mathrm{C}\right.$ dan $\left.61 \%\right)$ dan pada ketinggian $220 \mathrm{mdpl}\left(30.30^{\circ} \mathrm{C}\right.$ dan $\left.69 \%\right)$ dibandingkan pada ketinggian 1,280 mdpl $\left(26.70{ }^{\circ} \mathrm{C}\right.$ dan $\left.53 \%\right)$, mengakibatkan penurunan produksi biji habbatussauda aksesi India di ketinggian 560 mdpl sebesar $26.9 \%$ dan di ketinggian $220 \mathrm{mdpl}$ sebesar $44.5 \%$, sedangkan penurunan produksi biji habbatussauda aksesi Kuwait di ketinggian 560 mdpl sebesar 59.4\% dan di ketinggian 220 mdpl sebesar $63.9 \%$.

\section{UCAPAN TERIMA KASIH}

Penelitian ini merupakan Penelitian Unggulan Perguruan Tinggi (PUPTN) IPB, dengan skema Penelitian Unggulan Dasar Tahun 2015, dengan ketua Dr. Ani Kurniawati.

\section{DAFTAR PUSTAKA}

Abdolrahimi, B., P. Mehdikhani, A. Hasanzadeh-Gorttappe. 2012. The effect of harvest index, yield and yield components of three varieties of black seed (Nigella sativa L.) in different planting densities. Int. J. Agriscience. 2:93-101.

Ahmad, A., H. Diwan, Y.P. Abrol. 2010. Global climate change, stress and plant productivity. p. 503-521. In A. Pareek, S. K. Sopory, H. J. Bohnert, and Govindjee (Eds.). Abiotic Stress Adaptation in Plants: Physiological, Molecular and Genome Foundation. Springer Science, Business Media B.V.

Ahrens, C.D. 2009. Meteorology Today: An Introduction to Weather, Climate, and the Environment. 9th Edition. Cengage Learning Products, Education, Ltd., Canada.

Abas-Ali, M., M.A. Sayeed, M. Shahinur-Alam, M.S. Yeasmin, A.M. Khan, I.I. Muhamad. 2012. Charateristics of oils and nutrients contents of Nigella sativa L. and Trigonella foenum-graecum seeds. Bul. Chem.Soc. Ethiopia. 1:55-64.

Barnabás, B., K. Jäger, A. Feher. 2008. The effect of drought and heat stress on reproductive processes in cereals. Plant Cell Environ. 31:11-38.

Benkaci-Ali, F.A., Baliouamer, B.Y. Meklati, F. Chemat. 2007. Chemical composition of seed essential oil from Algerian Nigella sativa extracted by microwave and hydrodistillation. Flavour Frag. J. 22:148-153.

El-Mekawy, M.A.M. 2012. Growth and yield of Nigella sativa L. plan influenced by sowing date and irrigation treatment. American-Eurasian J. Agric. Environ. Sci. 12:499-505.

Farooq, M.,A. Wahid, N. Kobayashi, D. Fujita, S.M.A. Basra. 2009. Plant drought stress: Effect, mechanisms and management. Agron. Sustain. Dev. 299:185-212.

Gratani, L., F. Covone, W. Larcher. 2006. Leaf plasticity in response to light of tree evergreen species of the Medditerranean maquis. Trees. 20:549-558.

Hamid, M.E. 2012. Effect of Nigella sativa L. (black seed) extract on some clinically significant aerobic actinomycetes. J. Medicinal Plants Res. 6:339-341. 
Hedhly, A., J.I. Hormaza, M. Herrero. 2009. Global warming and sexual plant reproduction. Trends Plant Sci. 14:30-36.

Hua, J. 2009. From freezing to scorching, transcriptional responses to temperature variations in plants. Curr. Oppinion Plant Biol. 12:568-573.

Khoulenjani, M.B. and M.S. Salamati. 2011. Morphological reaction and yield of Nigella sativa $\mathrm{L}$. to Fe and $\mathrm{Zn}$. Afr. J. Agr. Res. 7:2359-2362.

Lumingkewas, A.M.W., Koesmaryono Y., Aziz S.A., Impron. 2015. The influence of temperature to Rutin concentration of Buckwheat grains in humid tropic. Int. J. Sci. Basic Appl Res. 20:1-9.

Muhuriah,L., K.N.Tyas, N.Khumaida, Trikoesoemaningtyas, D. Soepandie. 2006. Adaptasi tanaman kedelai terhadap intensitas cahaya rendah:karakter daun untuk efisiensi penangkapan cahaya. Bul. Agron. 34:133-140.

Ortiz, R., H.J. Braun, J. Crossa, J.H. Crouch, G. Davenport, J. Dixon. 2008. Wheat genetic resources enhancement by the International Maize and Wheat Improvement Center (CIMMYT). Genet. Res. Crop Evol. 55:10951140 .

Potters, G., T.P. Pasternak, Y. Guisez, M.A.K. Jansen. 2008. Different stresses, similar morphogenic responses: integrating a plethora of pathways. Plant Cell Environ. 32:158-169.

Rabbani, M.A., A. Ghafoor, M.S. Masood. 2011. NARCKalonji: An early maturing and high yielding variety of Nigella sativa released for cultivation in Pakistan. Pak J. Bot. 43:191-195.

Ridwan, T., M. Ghulamadi, A. Kurniawati. 2014. Laju pertumbuhan dan produksi jintan hitam (Nigella sativa L.) dengan aplikasi pupuk kandang sapi dan fosfat alam. J. Agron. Indonesia 42:158-165.

Sakata, T., A. Higashitani. 2008. Male sterility accompanied with abnormal anther development in plants-genes and environmental stresses with special reference to high temperature injury. Int. J. Plant Dev. Biol. 2:4251.

Shah, H.S. 2007. Influenced of combined application of nitrogen and kinetin on nutrient uptake and productivity of black cumin (Nigella sativa L.). Asian J. Plant Sciences. 6:403-406.
Shah, H.S. 2011. Gibberellic acid induced amelioration of salt stress in black cumin (Nigella sativa L.). Genet. Plant Physiol. 1:68-75.

Shah, H.S., I. Ahmad, Samiullah. 2006. Effect of gibbrellic acid spray on growth, nutrient uptake and yield attributes during various growth stages of black cumin (Nigella sativa L.). Asian J. Plant Sci. 5:881884.

Sharkey, T. D., R. Zhang. 2010. High temperature effects on electron and proton circuits of photosynthesis. J. Integr. Plant Biol. 52:712-722.

Suryadi, R. 2014. Karakter Morfologi dan Pemupukan $\mathrm{N}$ dan $\mathrm{P}$ Anorganik terhadap Pertumbuhan dan Produksi Bioaktif Thymoquinone Jintan Hitam. Thesis. Sekolah Pascasarjana. Institut Pertanian Bogor. Bogor.

Talafih, K.A., N.I. Haddad, B.I. Hatar, K. Kharallah. 2007. Effect of some agricultural practices on the productivity of black cummin (Nigella sativa) grown under rainfed semi-arid conditions. Jordan J. Agric. Sci. 3:385-397.

Thakur, P., S. Kumar, J.A. Malik, J.D. Berger, H. Nayyar. 2010. Cold stress effects on reproductive development in grain crops, an overview. Environ. Exp. Bot. 67:429-443.

Tian, J., F.C. Belanger, B. Huang. 2009. Identification of heat stressresponsive genes in heat-adapted thermal Agrostis scabra by suppression subtractive hybridization. J. Plant Physiol. 166, 588-601.

Tuncturk, R., M. Tuncturk, V. Ciftci. 2012. Effect of varrying nitrogens doses on yield and some yield components of black cumin (Nigella sativa L.). Adv. Environ. Biol. 6:855-858.

Tuncturk, M., R. Tuncturk, B. Y1ldırım. 2011. The effects of varying phosphorus doses on yield and some yield components of black cumin (Nigella Sativa L.). Adv. Environ. Biol. 5:371-374.

Wahid, A., S. Gelani, M. Ashraf, M.R. Foolad. 2007. Heat tolerance in plants: An overview. Env. Exp Bot. 61:199-223.

Zinn, K. E., M. Tunc-Ozdemir, J.F Harper. 2010. Temperature stress and plant sexual reproduction: Uncovering the weakest links. J. Exp. Bot. 61:1959-1968. 